\title{
THE FALL OF ROME RECONSIDERED: A SYNTHESIS OF MANPOWER AND TAXATION ARGUMENTS
}

\section{W. Richard Stephens, Jr.}

University of Kansas

Mid-American Review of Sociology, 1982, Vol. VII, No. 2:49-65

The arguments given for the decline and fall of Rome are many and varied. Two in particular have dominated the literature. One, supported by Max Weber, A.E.R. Boak and others, contends that the transition from ancient civilization to feudalism was due to the fall in supply of slaves and the ramifications of that fall on the ability of other elements in the system to be reproduced. A.H.M. Jones, A. Bernardi, C.M. Cipolla, and others have challenged this argument and have offered an alternative which focuses on the economic limitations of an agrarian based empire. The problem was manifest in an exceedingly oppressive system of taxation which also prevented system reproduction. These alternative arguments are synthesized in this paper by employing Marx's concept of reserve industrial army and explaining its operation with respect to various rates of exploitation. The result is a step to a more comprehensive explanation of Rome's decline and fall.

\section{INTRODUCTION}

In the German Ideology, Karl Marx outlines the fundamental stages of history. Beginning with tribal society Marx proposes two lines of development; one was the ancient societies of Rome and Greece, and the other was the oriental societies of India and China. He then goes on to examine the stage of feudalism and the transition to capitalism. With certain modifications, Weber implicitly incorporates Marx's outline in his studies of the Protestant Ethic, Judaism, China, India, etc. Of interest here is Weber's treatment of the transition from one stage to the next, in particular, the transition from the Ancient to the Feudal systems, which, interestingly enough, Marx omits. Although Rome eventually had two distinct parts, it is the Ancient society of Western Rome, as opposed to the Oriental system of the East, that is the subject of analysis here. 
At the center of Weber's argument was the issue of social reproduction; following his own historical studies, he concentrated upon the conditions for the reproduction of the slaveslavemaster relationship. Briefly, it was Weber's contention that the transition from Ancient civilization to Feudalism was due to the fall in supply of slaves, and the ramifications consequent upon the fall on the ability of other elements in that system to reproduce themselves. This argument could be referred to as a "manpower shortage" argument, and is supported by other scholars of Rome, notably, Arther E. R. Boak, in Manpower Shortage and the Fall of the Roman Empire in the West.

The manpower shortage argument however, has been challenged by some, including A.H.M. Jones, "Overtaxation and the decline of the Roman Empire"; Aurelio Bernardi, "The Economic Problems of the Roman Empire at the Time of its Decline"; and Carlo M. Cipolla, The Economic Decline of Empires. The main argument points to the economic limitations of an agrarian based empire. The problem was manifested in an exceedingly oppressive system of taxation which had severe consequences for the internal organization and the military defense of the state. The resulting semi-feudal system was incapable of supporting a large state.

It is the purpose of this analysis to show that the manpower shortage and taxation "camps" are not contradictory arguments, but can actually be merged to give a comprehensive and chronologically accurate explanation of the fall of the Roman Empire in the West. This will be done in the following way. First, notice of the prevailing conditions, for the most part self-evident, will be made in order to set the stage. A number of the items listed as initial conditions, although interesting and in other contexts worthy of further examination, will be taken as historical givens. Second, a description of the general state of affairs will be given for Classical Rome (the early empire, centuries one and two A.D.) and Decadent Rome (the later empire, centuries three through five). Thus having discussed the historical fact that the early Empire differed from the later Empire, an argument will be proposed merging the manpower shortage and taxation camps, which will explain the dynamics of the transition from Ancient to Early Feudal systems. The final result will be a completion of the arguments of Weber, Cipolla, and others, as well as providing a missing element of Marx's stages of history, the transition from Ancient to Feudal society. ${ }^{1}$

\section{PREVAILING CONDITIONS}

In order to understand the process whereby the Empire of Rome decayed it is important to know something about the environment in which it was operating. Up until the second century A.D. Rome was decidedly expansionistic. Periodic treasures flowed into the Empire; included in these treasures was a vast number of slaves. Rome was principally expanding into areas with high populations which were, significantly, similar in social organization and composition to itself. Therefore, the people enslaved were not merely unskilled, illiterate laborers, but were in fact at least as skilled as the native Romans in a variety of ways (Barrow, 1928; Gurowski, 1860; and Rostovtzeff, 1941).

By around the middle of the second century A.D., Roman military expansion had ceased. Once beyond the band of densely populated coastal nations of the Mediterranean, the available number and the relative skill (in terms of Roman needs) of the inhabitants reduced. Not only had the quality and quantity of the potential slave population been altered (Barrow, 1928), but the present means of expansion did not adapt well to the changes in geography and style of warfare of the natives (Luttwak, 1979; Marsden, 1969 and 1971; Parker, 1958; and Thompson, 1952). The military did not advance technologically, as did not the per capita productive capacity of the Roman citizenry in general.

To supplement its own technological level, Rome borrowed heavily from the conquered provinces and even from the barbarian frontierland. At its greatest extent, at the accession of Hadrian in 117, the territory of the Roman Empire embraced some 2,000,000 square miles and about $60,000,000$ inhabitantsmen, women, children, free men and slaves included. The Empire extended from the Euphrates River to the Atlantic, from the 
Sahara to the Rhine-Danube line, and most of Britain. The army which conquered and defended this domain numbered about 300,000 (Finley, 1970:85-86).

\section{CLASSICAL ROME}

Max Weber $^{2}$ defines three elements of the social structure of Antiquity. First, the civilization of Antiquity was essentially urban in character. The city was the center of political life, art, literature, and the economy. Second, the operation of the ancient city was based on the exchange of its industrial products for the agricultural products of its rural hinterland, an exchange centered in the city's own market. The trade involved was directly effected between producer and consumer, and essentially covered all needs; near self-sufficiency was the rule. What "international" trade did exist was limited primarily to a small number of expensive articles, luxuries. Third, the civilization of Antiquity was based upon slavery.

Because of the character of the chronic warfare of ancient civilization, potential labor, in the form of human enslavement, was abundantly available and, in Weber's words, cheap. The result of this was that the free sector ceased to expand; the crafts could not advance beyond the stage in which production was wage work done for customers by non-propertied artisans. Economic progress was manifest in the slave system by the steady accumulation of workers; the more slaves assembled, the more specialization of occupations was possible. Only slaveowners then could develop production based on a division of labor, and only they could improve their standard of living. More and more it was slave enterprises which could produce for both the needs of the master who lived in the city, and the needs of an exchange economy in the city marketplace. Thus, autarkic (self-sufficient) estates based on slave labor became the sole dynamic of the economy of Antiquity, and the slave/landowner became the dominant figure in the economy of Antiquity.

The conditions of life for the slave are of general interest and particular importance in this analysis; therefore, a brief outline of slave life is offered. "The speaking tools" (instrumentum vocale) were typically managed by the barracks system. Every aspect of the slave's life and every activity of the day was regimented. Further, the barracks slave was without either property or family. The significant element of this system concerned the constant demand for barracks replenishment; the barracks did not produce slaves. As Weber pointed out, "The ancient plantation consumed slaves the way a modern blast furnace consumes coal." Labor intensive operations were the rule and there was no room for workers whose activities detracted from their ability to produce. Hence, a slave market regularly and amply supplied with human material was the indispensable precondition for a barracks slave system engaged in market production.

The state of the Roman Empire in the first and second centuries was far from being a bureaucracy in the modern sense of the word (Rostovtzeff, 1927). The imperial officials, often paid in kind (Weber, 1978) were a mere superstructure added to self-governing communities throughout the Empire. The elective magistrates of these communities were the links that connected the citizen with the state. They had the municipal councils in Italy and the provinces had control over the town; duties included tax collection, care of legal matters, and enforcement of obligations such as making and maintaining roads. In most cases, the agents of the central government merely supervised the municipal authorities (Rostovtzeff, 1927).

The apparent self-sufficiency of the cities, and the relatively frequent contributions of the military to the national treasury created a situation in which the state did not have to make oppressive demands on its population. Although the military was already in the early stages of bureaucratization and the soldiers were paid a salary, the practice of taking booty after conquest did help defray its costs. The taxes which were assessed were generally of four kinds, a land tax, cattle tax, customs and duties, and a tax on the profits of any trade or profession. In special cases the city might levy some additional tax, but these were generally temporary in nature (Rostovtzeff, 1927). 
In summary, the picture of Classical Rome appears to include a relatively prosperous and smoothly operating system. As long as the society received an abundance of slaves (its necessary "fuel"), the system reproduced itself.

\section{DECADENT ROME}

The halt of expansion is the most obvious of differences. Weber points to the abandonment of the wars of conquest on the Rhine, a resolution later repeated on the Danube and Hadrian's evacuation of Dacia. The entire area of ancient civilization was now pacified internally and (to a large extent) externally (Weber, 1976:399).

Weber and others have noted that the most significant resource to which Rome had less access was the slave. In response, the barracks slave system of earlier times was replaced by one in which the slave was reunited with family and property and made a hereditary laborer of the estate-a serf.

With the change from barracks slave toward hereditary serf also came a reduction in the rate of production on the estates. ${ }^{3}$ This decrease in surplus market production, when combined with the migration from the country to the city during the prosperity of the first two centuries A.D., led to a clash of forces-decreased rural production and an increased urban demand (Bernardi, 1970:34-35).

Simultaneously, the Empire was still in need of a standing army. Once expansion halted and borders were established there was a need to defend those borders. A major contributor to the stability of the military was the periodic influx of treasures gained by conquest (Bernardi, 1970:32). Closely related to this was a change in the traditional operation of the Roman military. The change was from that of a service liturgically classified according to property and fulfilled by self-equipped men as an honorific privilege, to that of a state-equipped, "proletarian," bureaucratic army (or in other cases a mercenary army), the costs of which were met by general taxation (Weber, 1978b). As Weber has pointed out, due to massive accounting problems associated with payment in kind, there are few exceptions to the rule that bureaucracies must be supported with money payments. Thus the growth of a bureaucratic army implies the need for a fully developed money economy and a monetary taxation system (Weber, 1978b); but imbalance of rural-urban productive and consumptive forces already had resulted in an urban financial crisis (Bernardi, 1970:35).

Under the pretext that the towns were sunk in debt and incapable of managing their finances, special commissions were appointed by the Emperor to report on the facts; and from Trajan's time permanent inspectors discharged this office, steadily eclipsing the municipal authorities and reducing them to a position in which they were responsible to the state for the town and its territory, but entirely unable to act freely in town affairs (Rostovtzeff, 1927:260). The growth of the bureaucracy in the later Roman Empire further reduced the right of the municipal self-government; now the main activity of every social and economic center in the realm was interpreted as service to the state (Rostovtzeff, 1927:327).

There was resistance to this increased bureaucratization of the Empire, and it manifested itself in the growth of the large estates. Through a sympathetic alliance of large landowners, and high bureaucratic officials-themselves large landownerstaxation was avoided, evaded, and in some cases, legal immunity was granted (Bernardi, 1970:57-58). Due to these and other factors, the large estates were increasingly removed from jurisdiction and more and more came to internally produce all that they consumed. A great number of rural properties began to appear alongside the cities as administrative units, and in these holdings the landowners were the source of local authority. Given the impoverished condition of the urban centers, the state turned to the only remaining functional enterprise, the estate, to satisfy its needs (Weber, 1976:401).

Urban activities declined further, leaving as vital elements only those crucial to the state (Rostovtzeff, 1927:353). The labor in these operations amounted to state serfdom. Others, unable to bear the tax burden, sought the protection of the estate lords. In return for protection the smaller landowners became indebted to the lordsd; in effect, serfs (Bernardi, 1970:63). 
Thus, the entire population came under domination of some sort; the history of the time indicates that most preferred escape from cities to the estates.

As the estates became effectively self-sufficient the towns deteriorated rapidly. The economy of the Empire had fallen and the use of money was rare; yet the money needs of the military continued to exist. Confiscation and payment in kind proved inadequate at best, and the eventual solution was the barbarization of the legions (Bernardi, 1970:70-72). It was through these barbarian formations that the way was paved for the advent of the Roman-barbarian kingdoms on the soil of the Empire (Bernardi, 1970:72).

\section{SOCIAL STERILITY-WHY ROME FAILED TO REPRODUCE ITSELF}

In referring to social reproduction the emphasis is on the capacity of a system to continuously maintain its constituent social structures and the interrelationships among those structures. In the case of Rome the following are examples of structures and relationships which were not continuously reproduced, and thus were changed in form, operation, and contribution: (1) a bureaucratic army which was supported by taxes and geared towards defense as opposed to an honorific self-equipped army, (2) cities which were administered as tax sources by agents of the state bureaucracy as opposed to cities which were essentially self-administered, and (3) an economy which depleted its money reserves änd had forced people to seek refuge on the large self sufficient estates as opposed to one based on the intensive use of slaves and the circulation of goods between the urban centers and the rural estates. That these changes took place is a matter of historical fact; just how and why these changes took place is the subject of the following two parts of this section.

As noted in the introduction, there appear to be two relatively contrasting "camps" of explanation for the decline of Rome. Both are used, but with certain important modifications, in the following to provide the explanation of why Rome failed to reproduce itself. First, the manpower shortage and then the taxation arguments are presented.

\section{THE RESERVE SLAVE ARMY} Marx:

Consider the following quote from Vol. 1 of Capital, by

Taking them as a whole, the general movements of wages are exclusively regulated by the expansion and contraction of the industrial cycle. They are, therefore, not determined by the variations of the absolute number of working population, but by the varying proportions in which the working class is divided into active and reserve army, by the increase or diminution in the relative amount of the surplus population, by the extent to which it is now absorbed, now set free (1967:637).

The relevance of this passage is recognized when the question, "why is the size of the reserve industrial army related to the level of wages?" is asked. The answer is cloaked in terms of the rate of exploitation and how the rate operates, (a point Weber missed due to his inability to handle social structure).

In capitalism the individual capitalist has an unambiguous interest in getting as much production as he can out of each worker for the lowest cost. The worker likewise has an unambiguous interest in supporting and reproducing himself and his family. Given a condition in which there are other people, presently unemployed (and the absence of unions), yet willing and wanting to work-the reserve industrial army-and the condition that unemployment is below subsistence (i.e., the unemployed cannot long survive), there arises a special type of relationship between the capitalist and the wage laborer which results in a maximal rate of exploitation for the capitalist.

The cost for the capitalist of replacing a worker unwilling to produce at a maximum for subsistence wages is actually less than zero. By replacing the unwilling worker with one willing to work under the given conditions, the capitalist actually saves, thus, as long as the interests of the parties remain consistent, the rate of exploitation will reach, and be maintained at a maximum. However, in times of relative prosperity when need for labor increases, the relative size of the reserve industrial 
army decreases. Then the cost of replacing a worker increases, (due to the competition for available labor) and thus the rate of exploitation decreases.

In Rome there is an analogous structured process for the slave-slavemaster relationship. During the years of expansion slaves were available, cheap, and mobile (Barrow, 1928:120), (i.e., they could fill nearly any job required). The slaveowner, like the capitalist, had an unambiguous interest in getting the most production per slave possible. The cost of replacing a slave in the barracks system was equal to the cost of a new slave, and the cost of new slaves in the early Empire was quite cheap. Therefore, the costs to the slaveowner of "making an example" of a low producing slave (a painful death through torture, cruelty, etc., see Barrow, 1923) were low. Given this practice if the slave (like the wage laborer) has an unambiguous interest in his/her own self-preservation he/she will consequently produce as much as possible in order to avoid being the next "example." In short, the rate of coercive exploitation, given the existence of a relatively large reserve slave army, is at a maximum.

Although he does not develop the argument to the point which we have here, Marx does, earlier in Capital, make reference to the condition of the slave in terms of exploitation. As the following quote will show, Marx understood the situation of the slave under conditions of a maximum rate of exploitation, generated in part by a reserve army (although Marx does not label it as such).

The slave-owner buys his labourer as he buys his horse. If he loses his slave, he loses capital that can only be restored by new outlay in the slave-mart. But the rice-grounds of Georgia, or the swamps of the Mississippi may be fatally injurious to the human constitution; but the waste of human life which the cultivation of these districts necessitates, is not so great that it cannot be repaired from the teeming preserves of Virginia and Kentucky. Considerations of economy, moreover, which, under a natural system, afford some security for human treatment by identifying the master's interest with the slave's preservation, when once trading in slaves is practised, become reasons for racking to the uttermost the toil of the slave; for, when his place can at once be supplied from foreign preserves, the duration of his life becomes a matter of less moment than its productiveness while it lasts. It is accordingly a maxim of slave management, in slave-importing countries, that the most effective economy is that which takes out of the human chattel in the shortest space of time the utmost amount of exertion it is capable of putting forth (Marx, 1967:266).

Weber notes that the barracks slave system does not reproduce itself from within, slaves are replaced from without. He then asks the question, "what would happen if the slave market failed to make available an adequate quantity and quality of slaves?" (Weber, 1976:397-398). This is just what happened (see "Decadent Rome"), and its effect was similar to an increase in the demand for labor in capitalist systems. Slaves, due simultaneously to their scarcity and value in the Empire, were granted legal protections from slaveowners. Further, to each master the cost of buying a new slave was much greater. Thus, the rate of coercive exploitation for the slaveowner could not be maintained at a maximum.

The response of the slaveowners was to seek incentives to maintain production (Barrow, 1928:121). This took the form of reuniting the slave with family and property in the form of hereditary serfs (Weber, 1976:400-401). However, the reduced rate of coercive exploitation and the incentives reduced the rate of surplus. Since the master initially produced for himself and his household, the reduced rate of surplus was noticeable first, according to Weber, in the amount of surplus available for exchange in urban markets. The essential ingredient, money, was not being recirculated. The bureaucratic army and administration demanded payment in money, yet the production of surplus goods which had facilitated the necessary circulation of money was decreasing. Rome did not adjust, and in fact continued on in the same dead-end direction. It is at this point that the taxation arguments of Cipolla, Bernardi, Jones, etc., supply (with certain modifications) the concluding interpretation of this examination of the fall of Rome. 


\section{TAXATION AND COERCIVE EXPLOITATION}

An important point to recall is that although the empire was no longer expanding, the needs for military preparedness and maintenance remained (Weber, 1976:405). The significant point, however, is that the legions were no longer contributing to their own maintenance by bringing in treasures from without (Bernardi, 1970:32). This, when combined with the slowdown of the exchange economy in the cities set definite limits on the capacity of the Empire to reproduce itself.

The "solution" to the problem was an increased bureaucratization of the state, in which more effective management of the present resources was the goal (see "Decadent Rome"); and a subsequent increase in the rate of taxation, in order to support the military and the ever-growing bureaucracy. Like the capitalist and the slavemaster the Roman state was in a position in which its alternatives and interests were clear; or, as conceptualized earlier, the state's alternatives and interests were unambiguous. In order to maintain the present system, the state had to get the most out of an increasingly limited set of resources. Given the right of coercive taxation of the state, the solution to the problem of production was to raise the rate of coercive exploitation of available producers: in this case, Rome's population. The form of coercive exploitation was increased taxation.

The needs of the state and the productive capacity of the population were moving in opposite directions. The people, like the state, also had an unambiguous interest; it was manifest in attempts to circumvent, or escape the coercive exploitation of the state. As was the case, the brunt of the burden fell upon the shoulders of the small and medium-sized landowners (Rostovtzeff, 1927:315; Bernardi, 1970:48-51). At the same time larger landowners, through their alliance with the bureaucracy evaded taxation (see "Decadent Rome"). Eventually, the smaller landowners and the burdened classes of the cities sought and received the same type of evasion through the institution of the patrocinium; (the protection of the estates extended also to confiscation and mandatory military service) (Bernardi, 1970:69-70).
The crucial operation here is the reduction of the rate of coercive exploitation of the population by the state. It was not that the state wasn't interested in maintaining or increasing the present rate of coercive exploitation, but that due to certain factors (not to be explained here, but including the lack of military support of the bureaucracy's effort to tax due to occupation with the frontiers), the exploited population was able to escape state circumscription by seeking the protection and immunity of the large estates. This incapacity of the state to circumscribe a population is fundamental to the operation and reproduction of the state (Willer, 1977).

Since the state could no longer meet its needs through internal coercive exploitation, it again turned towards external resources. In this case, it was the fateful barbarization of the legions (Weber, 1976:407). But the "Empire" that was overrun was not the same as the one of the Classical period. Classical Rome had not been reproduced; the period of the final "fall" was already into the first stages of Feudalism.

\section{CONCLUSION}

In the proper sequence the manpower shortage and taxation camps, with the certain modifications proposed, form a more complete explanation of the decline of Rome in the West than do either alone. The initial stimulus is explicable in terms of the relative rates of coercive exploitation of the barracks slave. As the reserve slave army dwindled in size and narrowed in composition, there is reason to infer that the rate of coercive exploitation dropped. In turn, this led to a slowdown of surplus production essential to a money economy. However, the needs of the state remained, and in some respects increased.

The "solution" of the state was to increase the rate of taxation of its citizens. However, this led to escape from the domain of state taxation by movement to large estates. The final migration of the population from the cities to the estates was a migration from a system of higher to one of lower coercive exploitation. 
This shift in coercive exploitation rates served to reduce the overall economic base of the system from one of widespread exchange economies, to one of isolated self-sufficient, natural economies (Weber, 1976:409-411). Since these estates were withdrawing from the urban economy they could not pay taxes in money and thus could not support the bureaucratic army. The decentralized nature of such an organization impeded attempts by the state to maintain its size, structure, and operation. The standing army once composed of private landowners who supplied their own equipment, which evolved into one equipped by the state and recruited from the proletariat, now relied in great part on recruitment of barbarians from the border (Weber, 1976:405).

In summary, the preceding analysis has strived for, and hopefully has accomplished, the combination and completion of several apparently divergent modes of thought concerning the "fall" of the Roman Empire in the West. The shortcomings in Marx's stages of history were recognized in Weber's attempt to focus on the transition of Ancient to Feudal systems. The point of concern is social reproduction. In turn, Marxs' analysis of the reserve industrial army led to the analysis of the relation between the reserve slave army and the rate of coercive exploitation. The proper understanding of this led to a re-evaluation of the two main camps of thought concerning the fall of Romemanpower shortage and taxation. In both instances, the relative rates of coercive exploitation reduced first in the case of the reserve slave army, and second in the case of the tax exempt estate lords. The result was that the structures of Roman society which depended on the economy and consequently, the state and military, failed to be reproduced. The resulting system was unlike the former. Ancient society was now in the first stages of Feudalism.

\section{FOOTNOTES}

1. The decline of ancient civilization can be seen from two perspectives which are by no means mutually exclusive. Given that Rome in the west did succumb to barbarian invasions, the success of the barbarians could be seen (1) as a consequence of Rome's declining ability to defend itself, (2) as a consequence of increasing numbers and military sophistication of barbarians or, (3) as a simultaneous consequence of both. In fact there is very little evidence according to most sources concerning changes in barbarian population and sophistication in warfare (see Luttwak, 1979; Marsden, 1969 and 1971; Parker, 1958). In the absence of that evidence, this paper can be seen as supportive of either the first or third alternative above. Intertwined with the above alternatives is the issue of the style of defensive strategy adopted by Rome at various time periods. As Luttwak has pointed out, these strategies varied in "cost effectiveness" with early strategies being cheaper than later. An element of Luttwak's position is that earlier strategies suppressed barbarian pressure by the use of client states but, as these states were "used up" by the strategy, pressure directly upon Roman forces increased. With that increase came an increase in costs of defense. Clearly these costs did interact with the fiscal ability of Rome to maintain any defense. However, a full consideration of the relations between Luttwak's position and the points made here transcend the limits of this paper. Finally, it is stressed that this paper is not an attempt to be a complete analysis of the decline of the Roman Empire. Rather, it is an attempt to bring some unity, and thus more understanding, to the process which brought about Rome's decline.

2. Unless otherwise noted, this description of classical Rome is paraphrased from "Social Causes of Decline of Ancient Civilization," in Max Weber's, The Agrarian Sociology of Ancient Civilization, (London, 1976)

3. There has been much discussion on the relative contributions of slave and freeman in the overall economy of the Roman Empire. General consensus is that Rome was a slave society and any significant production was carried on by slaves brought in from outside the Empire. While some slaves were bred for offspring the relative low cost of slaves in the marketplace made this a generally unprofitable enterprise. Further, the "barracks" slave and "gang" production were encouraged by these were favorable conditions. The position that a che from "barracks" slave to hereditary serf resulted in a reduction in production on the estates is based on an understanding of the slave in production on the estates is based on an understanding of the slave mode of production, which implies a change away from a "barracks" system, would run in contradiction to a condition of ample "barracks" system, would run in supply. For discussions of this and related topics on the slave in the Roman Empire see, Ancient Rome at Work, by Paul-Louis (1927). Ancient Slavery and Modern Ideology, by M.I. Finley (1980); Slavery: A Comparative Perspective, edited by Robin W. Winks, (1972); Greek and Roman Slavery, by Thomas Wiedemann, (1981); and Conquerors and Slaves, by Keith Hopkins (1978). 


\section{REFERENCES}

Barrow, R. II

1928 Slavery in the Roman Empire. London: Methuen and Co. Ltd. Bernardi, A.

1970 "The Economic Problems of the Roman Empire at the Time of its Decline," in C.M. Cipolla (ed.), The Economic Decline of Empires. London: Methuen and Co. Ltd.

Boak, A.E.R.

1955 Manpower Shortage and the Fall of the Roman Empire in the West. Ann Arbor: University of Michigan Press.

Cipolla, C.M.

1970 The Economic Decline of Empires. London: Methuen and Co. Ltd.

Finley, M.I

1970 "Manpower and the Fall of Rome," in C.M. Cipolla (ed.), The Giddens, A. Economic Decline of Empires. London: Methuen and Co. Ltd.

1978 Capitalism and Modern Social Theory. N.Y.: Cambridge J. Press. Gurowski, A.

1860 Slavery in History. N.Y.: A.B. Burdick.

Jones. A.H.M

1955 "Overtaxation and the Decline of the Roman Empire," Antiquity (33).

Luttwak, E.

1979 The Grand Strategy of the Roman Empire. Baltimore: The Johns Hopkins University Press.

Marsden, E.W.

1969 Greek and Roman Artillery: Historical Development.

1971 Greek and Roman Artillery: Technical Treatises. Oxford: ClarenMarx, K. don Press.

1967. Capital, Vol. One. N.Y.: International Publishers.

Marx, K. and F. Engels

1964 The German Ideology. Moscow: Progress Publishers.

Parker, H.M.D.

1958 The Roman Legions. Cambridge: W. Heffer and Sons, Ltd.

Rostovtzeff, M.

1927 A History of the Ancient World.

1941 The Social and Economic History of the Hellenistic World, Vols. I and II. Oxford: Clarendon Press.

Thompson, E.A.

1952 A Roman Reformer and Inventor. Oxford: Clarendon Press.

Vogt, J.

1965 The Decline of Rome. London: Weidenfeld and Nicolson.
Weber, $M$.

1954 Law in Economy and Society. N.Y.: Simon and Schuster.

1964 Theory of Social and Economic Organization. N.Y.: Free Press.

1968 The Religion of China. N.Y.: Free Press.

1976 The Agrarian Sociology of Ancient Civilizations. London: NLB.

1978a From Max Weber. New York: Oxford University Press.

$1978 \mathrm{~b}$ Economy and Society. Los Angeles: University of California Press.

Webster, G.

1969 The Roman Imperial Army. London: Adam and Charles Black. Willer, D.

1977 "A Network Interpretation of Carneiro's Theory of the Origin of the State." Paper presented at the annual meeting of the American Anthropological Society, Houston, Texas. 